\title{
Nanoparticles as Novel Elicitors to Improve Bioactive Compounds in Plants
}

\author{
Samantha de Jesus Rivero-Montejo ${ }^{1}$, Marcela Vargas-Hernandez ${ }^{2}$ and Irineo Torres-Pacheco ${ }^{1, *}$ \\ 1 Laboratory of Biosystems Engineering, Faculty of Engineering, Campus Amazcala, Autonomous University \\ of Queretaro, Carretera a Chichimequillas, km 1 S/N, C.P., El Marques, Queretaro 76265, Mexico; \\ rivermon2014@gmail.com \\ 2 Faculty of Engineering, Campus Amealco, Autonomous University of Queretaro, Carretera Amealco \\ Temazcaltzingo, km 1, Centro, C.P., Amealco de Bonfil, Queretaro 76850, Mexico; marcela.vhz@gmail.com \\ * Correspondence: irineo.torres@uaq.mx; Tel.: +52-44-2192-1200
}

Citation: Rivero-Montejo, S.d.J.; Vargas-Hernandez, M.; TorresPacheco, I. Nanoparticles as Novel Elicitors to Improve Bioactive Compounds in Plants. Agriculture 2021, 11, 134. https://doi.org/ 10.3390/agriculture11020134

Academic Editor: Eva Johansson

Received: 1 January 2021

Accepted: 30 January 2021

Published: 6 February 2021

Publisher's Note: MDPI stays neutral with regard to jurisdictional claims in published maps and institutional affiliations.

Copyright: (c) 2021 by the authors. Licensee MDPI, Basel, Switzerland. This article is an open access article distributed under the terms and conditions of the Creative Commons Attribution (CC BY) license (https:// creativecommons.org/licenses/by/ $4.0 /)$.

\begin{abstract}
Bioactive compounds (e.g., flavonoids, phenolics acids, alkaloids and carotenoids) are commercially-valued products, due to their wide array of applications in the medical, pharmacological, cosmetic, agriculture and food industry. A strategy applied to increase or enhancing bioactive compounds production in plants is controlled elicitation. In recent years, many researchers have studied the role of nanoparticles (NPs) as a novel elicitor for the biosynthesis of bioactive compounds shown that the NPs could affect the plant's secondary metabolism in plant and culture systems. In this sense, recent studies have highlighted the potential applications of nanotechnology in crop production by improving the nutraceutical and nutritional quality of plants. In this review, we present studies about the application of NPs to enhance the production of bioactive plant metabolites. The aforementioned studies in ex vitro as in vitro, in addition to the effect of post-harvest by NPs application.
\end{abstract}

Keywords: bioactive compounds; nanoparticles; eustress; elicitation; secondary metabolic; ROS

\section{Introduction}

Bioactive compounds in plants are known as phytochemicals. In a strictly scientific sense, a bioactive compound is a substance that has a biological activity [1]. Among of positive effects of bioactive compounds in health are the reduction of developing chronic diseases, such as cancer and diabetes [2,3]. These health benefits are related to fruits and vegetables and they are attributed to the synergistic interactions of the bioactive compounds present in the food [4]. More than 5000 individual phytochemicals have been isolated and identified in fruits, vegetables and grains [5]. Among the principal bioactive compounds, we can find vitamin C, folate, provitamin A, potassium, calcium, magnesium, flavonoids, phenolics acids, alkaloids, carotenoids and fibers [6].

Bioactive compounds are a promising area in full development, fitting their applications in medicine, pharmacology, agrochemicals, cosmetics, the food industry and nanotechnology [7]. Due to the versatility of the effects of bioactive compounds, they are used in agro alimentary, perfumes, flavor, color and pharmacological preparations [8]. Moreover, the major role of secondary metabolites is the protection of plants from attack by insects, animals and pathogens or the survival of other biotic or abiotic stresses [9]. The aforementioned is important for increased or enhanced production of these compounds [10]. One approach to increasing these compounds' production is by targeting multiple signal transduction pathways in plants. However, the production of natural pathways by plants is low and it depends on different features such as the physiological and developmental stage of the plant [11]. Additionally, a strategy for incrementally increasing the production of these compounds is plant elicitation $[12,13]$. 
Stress is the principal method for the production of active secondary metabolites by plants and it can be simulated using various elicitors with active chemical defenses in the plant [14]. These elicitors can be biostimulants (a formulated product that can improve plant nutrition, plant productivity and others) and abiotic stresses [15]. Besides, other important strategies developed for the synthesis of bioactive compounds are precursor feeding, metabolic engineering, permeabilization, immobilization and bioreactor cultures [16]. A novel strategy is nanoparticles (NPs) which have been demonstrated that can be used as an elicitor in plants [14,17].

Nanotechnology is an emerging field of science that synthesizes and develops nanomaterials. NPs are defined as materials with sizes from 1-100 nm, which can be manufactured or natural [18]. NPs have attracted attention in recent years for the unique properties that they possess, which include morphology-aspect, chemically reactive, competitive binding sites and optically active. NPs may differ from the bulk material and they can have improved features based on their sizes, shape and structure [19]. NPs have potential uses in various branches of medicine, biotechnology, electronics, food and agriculture [14,20]. NPs are being used for a wide range of applications from medical treatments, optical devices, bactericidal, fungicidal, sensor technology and diverse materials commonly use from pictures to sunscreen [21]. Further, the unique properties of NPs have generated considerable attention in their agricultural application [22]. The principal application of nanomaterials in crop production is the reduction of the use of agrochemicals and increase of the yield through pest and nutrients management [23]. Recent studies have highlighted the potential applications of nanotechnology in crop production by improving yield, nutritional and nutraceutical value [24].

Different authors have reviewed the effect of nanoparticles on plants at the physiological, biochemical and genetic levels [25-29]. However, this paper includes a comprehensive and analytical account of the effects of nanoparticles in plants (e.g., fruits) and culture cells as potential elicitors under different culture conditions and systems. This review presents recent publications on the effect of NPs on the production of secondary metabolites in plants. Principally, this document focuses on nutraceuticals and nutritional compounds. In the Section 2, we present the nanoparticles and their features. In the Section 3, current studies of nanoparticles as elicitor and their effect in bioactive compounds production. The Section 4 is on the negative effects of NPs on plants and the possible risk for human health.

\section{Nanoparticles}

NPs are defined as materials with sizes from 1-100 $\mathrm{nm}$. The nanoparticles have been shown to have unique characteristics linked to their physical and chemical properties based on their nanoscale that differs from the bulk material [30-32]. The following details are important to consider to understand how the physical properties and bulk materials of NPs are related to biological interactions and functions for the elicitation of bioactive compounds on plants.

\subsection{Size}

One of the most important properties of nanoparticles is the size. In cells, the small size of NPs means they are not recognized as foreign, also allowing their entry through the membrane pores [33]. These features facilitate the diffusion in cells, which can be determined by the translocation and distribution in plants [34]. In plants, cell size affects not only the biodistribution but also the kinetics of release and cellular uptake [35]. Different studies on NPs uptake in plant protoplast and chloroplasts in vitro report that the size plays a role in translocation across the plant plasma membrane and organelle lipid bilayers [36,37]. However, Wang et al. [38] demonstrated that the translocation of Copper oxide (CuO) NPs, with a size of $20-40 \mathrm{~nm}$, from root to shoot is carried out through the xylem and phloem. The uptake of NPs can activate by various enzymatic and non-enzymatic defense systems [39], which can stimulate secondary metabolism production such as phytochemicals. Gupta et al. [40] demonstrate the phytostimulatory effect of bio-synthesized silver 
(Ag) NPs active the antioxidant enzyme activities and gene expression (catalase (CAT) and ascorbate peroxidase (APX) genes) coupled with $\mathrm{H}_{2} \mathrm{O}_{2}$ and lipid peroxidation was increased which accelerates the seedling growth in O. sativa L. and carotenoid contents. An advantage of this type of nanocompound is that the size can be adjusted depending on the desired applications [41]. For example, Avellan et al. [42] study the control foliar uptake, translocation and transport used a combination of golden NPs with different sizes $(3,10$ or $50 \mathrm{~nm})$ and coating chemistry (PVP vs citrate) showing that adhesion in leaf surface increased for smaller sizes in Wheat. This suggests that the application method has an effect, based on different morphologies, of NPs uptake in plants; as consequence, this may affect the secondary metabolism stimulation.

\subsection{Shapes}

The shapes of nanoparticles also exert an impact on their properties. The NPs can have structural arrangements with various morphological shapes such as sharp, rod, triangle, round, octahedral, polyhedral and so forth. Further, the NPs have different porous shapes, such as nanorod, porous spheres, nanohusk, nanocubes, distorted cubes and self-oriented flowers [43]. These characteristics affect the cellular internalization, circulation time, biodistribution and residency time through the cells [35,44]. Raliya et al. [45] demonstrated that the Golden $(\mathrm{Au})$ NPs with a sphere, cube and rhombic dodecahedra shapes are accumulated in leaf, stem and root in plants; in this way, they enhanced their transport, depending on the NPs shape. On the other hand, elongated NPs show higher efficiency adhering to the cells, as a result of a higher aspect ratio, while the curve shape has a limited number of binding sites [46,47].

\subsection{Nanomaterials}

There are different types of nanomaterials such as ferromagnetic, ferroelectric and super-conducting [48]. Nanomaterials show different properties, which depend on their size and shape [49]. Also, nanomaterials can be classified into three types-one (thin films or coatings attached on a substrate), two (porous films with nanoscale pores, long aspect ratio fibers, wires or tubes) and three (membranes with nanopores on a substrate) dimensions in the nanoscale regime [50]. Further, the nanomaterial can be classified from the material bulk: Carbon-based (carbon nanotubes, graphene and fullerenes, metal-based including zero-valent metals $(\mathrm{Au}, \mathrm{Ag}$ and $\mathrm{Fe})$, metal-oxides $\left(\mathrm{ZnO}, \mathrm{TiO}_{2}, \mathrm{CeO}_{2}\right)$, metal salts (nano silicates and ceramics), quantum dots (CdSe and $\mathrm{CdTe}$ ) and nanosized polymers (dendrimers and polystyrene) [51]. The importance of the influence of the nanomaterial is that there can be significant differences in effect or accumulation as a function of the chemical form (NPs or ionic) [52,53]. Bradfiel et al. [54] study zinc (Zn), copper (Cu) or cerium (Ce) accumulation from metal oxide NPs or ions in sweet potato reported adverse effects on tuber biomass for the highest concentration of $\mathrm{Zn}$ or $\mathrm{Cu}$ contrary of Ce exposure, which had no adverse effects and a slight positive benefit on tuber diameter.

\section{Nanoparticles as an Elicitor}

Nanoparticles have the potential to be used as a novel abiotic elicitor for the induction of bioactive compounds in plant cell and tissue culture [28]. In recent years, many researchers have studied the role of nanoparticles as an elicitor for inducing the expression of genes involved in the biosynthesis of secondary metabolites [55]. Although many efforts are still required to elucidate the mechanism, some authors have proposed that NPs induce reactive oxygen species (ROS) and secondary signaling messengers that lead to transcriptional regulation in plant secondary metabolism [25]. ROS and calcium ions $\left(\mathrm{Ca}^{2+}\right)$ are important second messengers leading to the up-regulation of transcriptional regulators of secondary metabolites [29]. The activation or inactivation of oxidative stress depends on several factors including plant species [56], age and type of tissues [57], tolerance or sensible in plants and the type of stressor [58]. Several studies reported that NPs application have 
resulted in an accumulation in the plant cell of ROS which triggers oxidative stress and, thus subsequent direct and indirect changes in primary and secondary metabolites [25].

Nutraceuticals and Nutritional Compounds Induction Using NPS

Several studies have shown that the NPs could affect the primary and secondary metabolism in vitro and ex vitro. To support the notion of NPs as elicitors, all the studies provided evidence that the NPs have the potential to induce plant bioactive compounds' production (Table 1).

Within the nutritional changes that NPs cause in plants, the synthesis of various primary metabolites has also been observed. Zhao et al. [62] reported the effects of Cu NPs in cucumber fruits exposed to different concentrations; as a result, they detected an increase of essential amino acids such as valine $(16 \%-32 \%)$, leucine $(13 \%-41 \%)$, isoleucine $(12 \%-28 \%)$, threonine $(0.1 \%-18 \%)$ and tyrosine $(0.1 \%-32 \%)$. Further, this investigation demonstrated an up-regulated by $\mathrm{Cu}$ NPs at several metabolites such as xylose, fructose, glycine, proline, benzoic acid, glutaric acid, caprylic acid and linolenic acid [62]. An interesting example is the effects of cerium oxide nanoparticles (Ce NPs) in tomato fruits, the results showed an increase of metabolic at lycopene. Barrios et al. [64] studied the effect in tomato fruits after exposure to Citric acid-coated cerium oxide nanoparticles (Ce NPs + CA). The results at 210 days showed an increase of $16.57 \pm 4.48 \mathrm{mg} / \mathrm{kg}$ of lycopene content at $125 \mathrm{mg} / \mathrm{kg}$ to Ce NPs + CA, in comparison to $7.50 \pm 2.45 \mathrm{mg} / \mathrm{kg}$ for the control. These results indicated that the exposition of $\mathrm{Cu}$ NPs induces alteration of secondary and primary metabolites in plants and also, these changes can be present post-harvest.

Diverse secondary metabolites are increased in plants when they are under the effect of NPs. Večeřová et al. [61] studied the effect on the leaves and roots of barley plants of being exposed to $2.03 \pm 0.45 \times 10^{5} \mathrm{CdO}$ NPs per $\mathrm{cm}^{3}$; they reported an increase in the total content of phenolic compounds by approximately 200 times, principally the ferulic acid and saponarin in leaves and roots. Also, the authors reported an increase in the isovitexin content by 183\% [61]. Recently, polyphenols have received the attention of scientists and consumers, due to their potential medicinal properties in the prevention and cure of various degenerative diseases, particularly cancers, cardiovascular diseases and neurodegenerative diseases [81]. Li et al. [76] found that foliar application of $5 \mathrm{mg} / \mathrm{L}$ of selenium (Se) NPs in celery enhanced the total antioxidant capacity $(46.7 \%)$, total flavonoids $(50 \%)$, such as apigenin, p-coumaric acid, ferulic acid, luteolin and kaempferol, total phenols $(21.4 \%)$ and vitamin C (26.7\%). 
Table 1. Summary associated with nanoparticles (NPs) as an elicitor for bioactive compounds.

\begin{tabular}{|c|c|c|c|c|c|c|c|}
\hline Nanoparticles & Size & Concentration & NPs Treatment & Plant & Tissue/Organ & Effects & Reference \\
\hline $\begin{array}{l}\text { Cu absorbed on } \\
\text { chitosan hydrogel }\end{array}$ & & $\begin{array}{c}100 \mathrm{mg} / \mathrm{kg} \\
0.3,0.15,0.06 \\
0.03 \text { and } 0.015 \mathrm{~g} / \mathrm{L}\end{array}$ & $\begin{array}{l}\text { One time only prior } \\
\text { to transplantation }\end{array}$ & $\begin{array}{l}\text { Saladette tomato } \\
\text { hybrid variety "Toro" } \\
\text { (Solanum } \\
\text { lycopersicum) }\end{array}$ & $\begin{array}{l}\text { Seedlings, fruits } \\
\text { and leaves }\end{array}$ & $\begin{array}{l}\text { An increment of lycopene, titratable acidity } \\
\text { and catalase activity, }\end{array}$ & [59] \\
\hline $\begin{array}{l}\text { Cu absorbed on } \\
\text { chitosan hydrogel }\end{array}$ & $25 \mathrm{~nm}$ & $\begin{array}{l}0.02,0.2,2 \text { and } 10 \\
\mathrm{~m}(\mathrm{nCu}) \mathrm{g}^{-1} \\
(\mathrm{Cs}-\mathrm{PVA})\end{array}$ & $\begin{array}{l}\text { One time only prior } \\
\text { to transplantation }\end{array}$ & $\begin{array}{l}\text { Jalapeño pepper } \\
\text { (Capsicum annuum L.) }\end{array}$ & Fruits & $\begin{array}{l}\text { Rise the content of antioxidants ABTS and } \\
\text { DPPH, total phenols and flavonoids, } \\
\text { titratable acidity and reduce of loss weight } \\
\text { in fruits post-harvest }\end{array}$ & [60] \\
\hline $\mathrm{CdO}$ & $7-60 \mathrm{~nm}$ & $\begin{array}{l}2.03 \pm 0.45 \times 105 \\
\text { CdONPs particles } \\
\text { per } \mathrm{cm}^{3} \text { of air. }\end{array}$ & 3 weeks & $\begin{array}{l}\text { Barley (Hordeum } \\
\text { vulgare L.) }\end{array}$ & Leaves-root & $\begin{array}{l}\text { Increased of ferulic acid, saponarin, palmitic } \\
\text { acid, linoleic acid, isovitexin, phenylalanine } \\
\text { and tryptophan, reduction of flavonol, } \\
\text { reductions in maximum quantum yield of } \\
\text { photosystem II photochemistry, decrease of } \\
\text { saccharides except 2-deoxy-D-ribose, } \\
\text { reduction of fatty acids in roots }\end{array}$ & [61] \\
\hline $\mathrm{Cu}$ & $40 \mathrm{~nm}$ & $\begin{array}{l}0,200,400 \text { and } \\
800 \mathrm{mg} / \mathrm{kg}\end{array}$ & $\begin{array}{l}\text { Soil pre-treated with } \\
\text { a suspension of } \mathrm{nCu}\end{array}$ & $\begin{array}{c}\text { Cucumber } \\
\text { (Cucumis sativus) }\end{array}$ & Fruits & $\begin{array}{l}\text { Augmentation of valine, leucine, isoleucine, } \\
\text { threonine, tyrosine, xylose, fructose, glycine, } \\
\text { proline, benzoic acid, glutaric acid, caprylic } \\
\text { acid, linolenic acid and imidazole. Decrease } \\
\text { of lysine and methionine }\end{array}$ & [62] \\
\hline $\begin{array}{l}\text { Cerium oxide } \\
\left(\mathrm{nCeO}_{2}\right) \text { and Citric } \\
\text { acid coated cerium } \\
\text { oxide }\left(\mathrm{nCeO} \mathrm{CeO}_{2}+\mathrm{CA}\right)\end{array}$ & $\begin{array}{c}\mathrm{nCeO}_{2}: 8 \pm 1 \\
\text { (primary size) } \\
\text { and } 231 \pm 16 \\
\text { (in deion- } \\
\text { ized water) } \\
\mathrm{nCeO}_{2}+\mathrm{CA}: \\
12.4 \mathrm{~nm} \\
\text { (primary size) } \\
\text { and } 189 \pm 2 \text { (in } \\
\text { deionized } \\
\text { water) }\end{array}$ & $\begin{array}{c}0,62.5,125,250 \text { and } \\
500 \mathrm{mg} / \mathrm{kg}\end{array}$ & $\begin{array}{l}\text { Soil pre-treated with } \\
\text { a suspension of } \\
\mathrm{nCeO}_{2} \text { and } \\
\mathrm{nCeO}_{2}+\mathrm{CA}\end{array}$ & $\begin{array}{l}\text { Roma tomato } \\
\quad(\text { Solanum } \\
\text { lycopersicum })\end{array}$ & Fruits & $\begin{array}{c}\text { Increased of lycopene. } \mathrm{nCeO}_{2}+\mathrm{CA} \text { decrease } \\
\text { reducing sugar, reduce starch, } \mathrm{nCeO}_{2} \text { reduce } \\
\text { copper, manganese, magnesium, } \\
\text { calcium and iron }\end{array}$ & [63] \\
\hline
\end{tabular}


Table 1. Cont

\begin{tabular}{|c|c|c|c|c|c|c|c|}
\hline Nanoparticles & Size & Concentration & NPs Treatment & Plant & Tissue/Organ & Effects & Reference \\
\hline MeJA and Ag & $40 \mathrm{~nm}$ & $\begin{array}{c}\text { MeJA: } 50 \text { and } 100 \mu \mathrm{M} \\
\text { Ag: } 0.4,0.8,1.2 \mathrm{mM}\end{array}$ & $24 \mathrm{~h}$ by hydroponic & $\begin{array}{l}\text { Marigold (Calendula } \\
\text { officinalis L.) }\end{array}$ & Aerial part & $\begin{array}{c}\text { Enhance of saponin and the reduction of } \\
\text { HeLa cells was more pronounced, increase } \\
\text { membrane lipid peroxidation. Decreased } \\
\text { anthocyanin, flavonoid and DPPH radical } \\
\text { scavenging activity chlorophyll production } \\
\text { and carotenoid }\end{array}$ & {$[64]$} \\
\hline $\mathrm{CuO}$ & NR & $1 \mathrm{ppm}$ & In solution & $\begin{array}{c}\text { Ashwagandha } \\
\text { (Withania somnifera L. } \\
\text { Dunal) }\end{array}$ & Shoots and roots & $\begin{array}{l}\text { Polyphenols (total phenol content, flavonoid } \\
\text { content) and antioxidant activity }\end{array}$ & [65] \\
\hline $\begin{array}{l}\mathrm{Ag}, \mathrm{Au} \text { and } \\
\text { Naphthalene acetic } \\
\text { acid (NAA) }\end{array}$ & NR & $\begin{array}{l}30 \mu \mathrm{g} / \mathrm{L} \text { of each NPs } \\
\text { in ratios of AgAu: } \\
\text { 1:2; } 1: 3 ; 2: 1 \text { and } 3: 1 \\
\text { with NAA }\end{array}$ & $\begin{array}{l}\text { One time only added } \\
\text { to the culture media }\end{array}$ & $\begin{array}{l}\text { Selfheal (Prunella } \\
\text { vulgaris L.) }\end{array}$ & Calli cultures & $\begin{array}{l}\text { Improved biomass, total phenols and } \\
\text { flavonoids and DPPH-radical } \\
\text { scavenging activity }\end{array}$ & [66] \\
\hline $\mathrm{Ag}$ & $30-50 \mathrm{~nm}$ & $0,2.5,5$ and $10 \mathrm{ppm}$ & $\begin{array}{l}\text { One time only added } \\
\text { to the culture media }\end{array}$ & $\begin{array}{l}\text { Hazel (Corylus } \\
\text { avellana L. cv. Gerd } \\
\text { Eshkevar) }\end{array}$ & Hazel cells & $\begin{array}{l}\text { Increased taxanes content (taxol and } \\
\text { baccatin III) and reduce the viability of HeLa } \\
\text { cells at } 55 \% \text {, increased lipid peroxidation. } \\
\text { Decreased the content of total soluble } \\
\text { phenols and the total contents of flavonoids }\end{array}$ & [67] \\
\hline $\mathrm{AgNPs}$ and $\mathrm{AgNO}_{3}$ & NR & $0.5,1.0$ and $2.0 \mathrm{mg} / \mathrm{L}$ & $\begin{array}{l}\text { One time only added } \\
\text { on } 18 \text { days to the } \\
\text { culture media }\end{array}$ & $\begin{array}{l}\text { Gherkin (Cucumis } \\
\text { anguria L.) }\end{array}$ & Hairy root & $\begin{array}{l}\text { Increment the biomass accumulation, } \\
\text { total phenols content (hydroxybenzoic acid, } \\
\text { protocatechuic, syringic, } \beta \text {-resorcylic, } \\
\text { vanillic acid, caffeic, chlorogenic, } \\
\rho \text {-coumaric, ferulic, o-coumaric and } \\
\text { t-cinnamic) and biological activity } \\
\text { (antioxidant, antibacterial, antifungal and } \\
\text { anticancer). Reduced of biomass }\end{array}$ & [68] \\
\hline $\mathrm{ZnO}$ and $\mathrm{CuO}$ & $\begin{array}{l}\mathrm{ZnO}: 20-30 \mathrm{~nm} \\
\mathrm{CuO}: 25-30 \mathrm{~nm}\end{array}$ & $\begin{array}{l}0,2,20,200 \text { and } \\
2000 \mathrm{mg} / \mathrm{L}\end{array}$ & $\begin{array}{l}\text { One time only added } \\
\text { to the culture media }\end{array}$ & $\begin{array}{l}\text { Candyleaf (Stevia } \\
\text { rebaudiana) }\end{array}$ & Shoots & $\begin{array}{l}\text { Up of rebaudioside A, stevioside content, } \\
\text { total phenolic content, total flavonoid } \\
\text { content, total antioxidant activity, } \\
\text { total reducing power and \% DPPH } \\
\text { inhibition. In higher concentration reduce } \\
\text { weight and quality of callus }\end{array}$ & [69] \\
\hline
\end{tabular}


Table 1. Cont.

\begin{tabular}{|c|c|c|c|c|c|c|c|}
\hline Nanoparticles & Size & Concentration & NPs Treatment & Plant & Tissue/Organ & Effects & Reference \\
\hline $\begin{array}{l}\mathrm{ZnO} N P s, \\
\text { jasmonate and } \\
\text { chittosan }\end{array}$ & NR & $\begin{array}{c}\text { ZnO; } 20,60 \text { and } \\
100 \text { ppm } \\
\text { Jasmonate: } 100, \\
250 \text { and } 500 \mu \mathrm{M} \\
\text { Chittosan: } 10,50 \text { and } \\
100 \mu \mathrm{M}\end{array}$ & Foliar sprays & $\begin{array}{l}\text { Carla (Momordica } \\
\text { charantia L.) }\end{array}$ & Shoots & $\begin{array}{l}\text { Rise of phenols, flavonoids, anthocyanin } \\
\text { content and carotenoids as well as } \\
\text { carbohydrate, proline content and } \\
\text { up-regulated antioxidant enzyme activity. }\end{array}$ & [70] \\
\hline $\mathrm{Ag}$ & NR & $\begin{array}{c}0,0.25,0.5,1,1.5 \text { and } \\
2 \mathrm{mg} / \mathrm{L}\end{array}$ & $\begin{array}{l}\text { One time only added } \\
\text { to the culture media }\end{array}$ & Isatis (Isatis constricta) & Plantlets & $\begin{array}{l}\text { Increased of indigo and tryptanthrin but } \\
\text { decreased on } 10 \text { and } 15 \text { days post-treatment } \\
\text { and indirubin decreased }\end{array}$ & {$[71]$} \\
\hline $\begin{array}{c}\mathrm{SiO}_{2} \text { and } \mathrm{TiO}_{2} \mathrm{NPs} \\
\text { and } \mathrm{NaCl}\end{array}$ & $\begin{array}{l}\mathrm{SiO}_{2}: 10-15 \mathrm{~nm} \\
\mathrm{TiO}_{2}: \\
\text { an average of } \\
24.5 \mathrm{~nm}\end{array}$ & $\begin{array}{l}\mathrm{SiO}_{2} \text { and } \mathrm{TiO}_{2} \mathrm{NPs}: \\
25 \text { and } 50 \mathrm{mg} / \mathrm{L} \\
\mathrm{NaCl}: 0.3 \mathrm{M}\end{array}$ & $\begin{array}{l}\text { One time only added } \\
\text { to the pot }\end{array}$ & $\begin{array}{l}\text { Feverfew (Tanacetum } \\
\text { parthenium } \mathrm{L} .)\end{array}$ & Leaves & $\begin{array}{c}\text { Increment of parthenolide, } T p C a r S, C O S T \\
\text { and TpGAS gene involved parthenolide and } \\
\beta \text {-caryophyllen biosynthesis pathway }\end{array}$ & [72] \\
\hline $\mathrm{SiO}_{2}$ and $\mathrm{TiO}_{2}$ & $\begin{array}{l}\mathrm{SiO}_{2}: 5-15 \mathrm{~nm} \\
\mathrm{TiO}_{2}: \\
\text { an average of } \\
25 \mathrm{~nm}\end{array}$ & $\begin{array}{l}5,10 \text { and } 20 \text { ppm } \\
\text { after } 15 \text { days of } \\
\text { incubation }\end{array}$ & $\begin{array}{c}\text { One time only added } \\
\text { to the MS medium } \\
\text { supplemented with } \\
4.5 \mu \mathrm{M} 2,4- \\
\text { dichlorophenoxyacetic } \\
\text { acid and } 5 \mu \mathrm{M} \text { NAA }\end{array}$ & $\begin{array}{l}\text { Argan (Argania } \\
\text { spinosa) }\end{array}$ & $\begin{array}{l}\text { Callus culture } \\
\text { (leaves) }\end{array}$ & Enhance $\alpha$-tocopherol accumulation & [73] \\
\hline$n \mathrm{TiO}_{2}$ and $b \mathrm{TiO}_{2}$ & $\begin{array}{l}n \mathrm{TiO}_{2}:<50 \mathrm{~nm} \\
\text { and } b \mathrm{TiO}_{2}: \\
\quad 68 \mathrm{~nm}\end{array}$ & $\begin{array}{l}200 \text { and } 800 \mathrm{mg} / \mathrm{kg} \\
\text { mixed in potting soil }\end{array}$ & $\begin{array}{l}\text { Mix one time in soil } \\
\text { (2 kg soil for pot) }\end{array}$ & $\begin{array}{l}\text { Okra (Abelmoschus } \\
\text { esculentus L. } \\
\text { (Moench)) }\end{array}$ & $\begin{array}{l}\text { Roots, leaves } \\
\text { and fruits }\end{array}$ & $\begin{array}{l}\text { Promoted seed germination, enhanced } \\
\text { chlorophylls, increment superoxide } \\
\text { dismutase (SOD), reduce ascorbate } \\
\text { peroxidase (APX) and glutathione reductase } \\
\text { (GR) in roots. In leaves reduce APX, } \\
\text { increased GR and malondialdehyde. In fruit } \\
\text { increased } \mathrm{Na} \text {, reduced } \mathrm{Ca}, \mathrm{Mg} \text { and Fe }\end{array}$ & [74] \\
\hline $\mathrm{Ag}$ & $\begin{array}{l}10,40 \text { and } \\
100 \mathrm{~nm}\end{array}$ & $0.5,1.0,5.0 \mathrm{mg} / \mathrm{L}$ & $\begin{array}{l}12,24 \text { and } 72 \mathrm{~h} \text { in } \\
\text { MS medium }\end{array}$ & $\begin{array}{c}\text { Mouseear cress } \\
\text { (Arabidopsis thaliana) }\end{array}$ & Seedlings & $\begin{array}{l}\text { An increment of glutathione disulphide, } \\
\text { 6-GluO-ICOOGlu, 4-glucosyloxy-benzoate, } \\
\text { 4-hydroxyglucobrassicin, sinapoyl malate, } \\
\text { kaempferitrin, G(8-5)FA dihexoside, } \\
\text { G(8-0-4)G hexoside, 6-MeO-ICOOH, sinapic } \\
\text { acid, G(8-0-4)G(8-0-4)G hexoside, } \\
\text { coniferylaldehyde hexoside and camalexin. } \\
\text { Decreased of 4-glucosyloxy-benzoate, } \\
\text { pinresinol hexoside and } \\
\text { kaempferol-3-O-glucoside }\end{array}$ & [75] \\
\hline
\end{tabular}


Table 1. Cont

\begin{tabular}{|c|c|c|c|c|c|c|c|}
\hline Nanoparticles & Size & Concentration & NPs Treatment & Plant & Tissue/Organ & Effects & Reference \\
\hline Se & $50-78 \mathrm{~nm}$ & $5 \mathrm{mg} / \mathrm{L}$ & $\begin{array}{l}\text { Sprayed on the stems } \\
\text { and leaves every } \\
10 \text { days (three times } \\
\text { total applications) }\end{array}$ & $\begin{array}{l}\text { Celery (Apium } \\
\text { graveolens L.) }\end{array}$ & Stems-leaves & $\begin{array}{l}\text { Increased of chlorophyll, soluble sugar, } \\
\text { proteins, beta-carotenes, ariginine, } \\
\text { tryptophan, aspartic acid, glutamic acid, } \\
\text { proline, jasmonic acid, total antioxidant } \\
\text { capacity, vitamin C, total phenols } \\
\text { and flavonoids }\end{array}$ & [76] \\
\hline $\mathrm{ZnO}$ and $\mathrm{NaCl}$ & $10-30 \mathrm{~nm}$ & $\begin{array}{c}\mathrm{ZnO}: 0,20,40 \text { and } \\
80 \mathrm{mg} / \mathrm{L} \\
\mathrm{NaCl}: 0,50 \text { and } \\
100 \mathrm{mM}\end{array}$ & $\begin{array}{l}\text { Foliar sprays of } \mathrm{NPs} \\
\text { (two times) and } \mathrm{NaCl} \\
\text { irrigation (in } \\
\text { greenhouse) }\end{array}$ & $\begin{array}{c}\text { Camelina } \\
\text { (Camelina sativa) }\end{array}$ & Shoot-root & $\begin{array}{l}\text { Rise of total phenol content, anthocyanins, } \\
\text { carotenoid calcium, zinc and phosphorus. } \\
\text { Decreased antioxidant capacity, } \\
\text { total flavonoid content }\end{array}$ & [77] \\
\hline $\mathrm{ZnO}$ & NR & 100 and $150 \mathrm{mg} / \mathrm{L}$ & $\begin{array}{l}\text { One time added to } \\
\text { the MS medium } \\
\text { supplemented with } \\
2 \mathrm{mg} / \mathrm{L} \mathrm{2,4-D} \mathrm{and} \\
2 \mathrm{mg} / \mathrm{L} \mathrm{Kin}\end{array}$ & $\begin{array}{l}\text { Garden thyme } \\
\text { (T. vulgaris), } T \text {. } \\
\text { daenensis, } T \text {. } \\
\text { kotschyanus and Satar } \\
\text { (Zataria multiflora) }\end{array}$ & Callus culture & $\begin{array}{l}\text { Augmentation of thymol and } \\
\text { carvacrol content }\end{array}$ & {$[78]$} \\
\hline $\mathrm{Ag}$ & $40 \mathrm{~nm}$ & 30,60 and $90 \mu \mathrm{g} / \mathrm{L}$ & $\begin{array}{l}\text { One time added to } \\
\text { the MS medium } \\
\text { supplemented with } \\
0.5 \mathrm{mg} / \mathrm{L} \mathrm{2,4-D} \mathrm{and} \\
3.0 \mathrm{mg} / \mathrm{L} \mathrm{BA}\end{array}$ & Caralluma tuberculata & Callus culture & $\begin{array}{l}\text { An increment of fresh and dry biomass } \\
\text { accumulation, total phenols and flavonoids } \\
\text { content, PAL, SOD, POD, CAT and APX. }\end{array}$ & [79] \\
\hline $\begin{array}{l}\text { Mesoporous silica } \\
\text { functionalized with } \\
\text { amines and } \mathrm{TiO}_{2}\end{array}$ & $165 \mathrm{~nm}$ & $\begin{array}{c}1 \mu \mathrm{g} / \mathrm{mL}, 10 \mu \mathrm{g} / \mathrm{mL} \\
100 \mu \mathrm{g} / \mathrm{mL} \\
1 \mathrm{mg} / \mathrm{mL} \text { and } \\
2.5 \mathrm{mg} / \mathrm{mL}\end{array}$ & $\begin{array}{l}\text { One time added to } \\
\text { the MS medium }\end{array}$ & $\begin{array}{l}\text { Gray goldenroad } \\
\text { (Solidago nemoralis) }\end{array}$ & Hair root culture & $\begin{array}{c}\text { Increased of antiradical activity, flavonoids, } \\
\text { include the continued flavonoid synthesis } \\
\text { after harvest. }\end{array}$ & {$[80]$} \\
\hline
\end{tabular}


Furthermore, a synergistic effect between NPs and other types of compounds has been demonstrated. Juarez-Maldonado et al. [59] studied the effect of Copper (Cu) NPs in chitosan hydrogels $(0.06 \mathrm{~g} / \mathrm{L})$ in tomato fruits 15 days after post-harvest showing a $12 \%$ increase in lycopene concentration and nutritional characteristics in comparison to the control. Similar effects are observed when $\mathrm{Cu}$ NPs in chitosan-PVA hydrogels were put in the soil before transplantation in jalapeño pepper, with an increase in the content of capsaicin up to $51 \%$ in comparison to the control [60]. These authors also reported an increase of $23.9 \%$ of DPPH antioxidants, $1.54 \%$ of total phenols and $17.2 \%$ of flavonoids; these results demonstrated not only effects on the development of the fruit but also modified the post-harvest characteristics along the time [60]. Besides, these stimulatory effects related to the induction of antioxidant activity have been shown in $\mathrm{Cu}$ NPs [82]. Moreover, not only have been carried out studies about NPs and their interaction with other compounds (ex. Coating) as elicitors but also with abiotic stresses such as drought or salinity. $\mathrm{TiO}_{2}$ and $\mathrm{SiO}_{2} \mathrm{NPs}$ and salinity stress treatment to increase parthenolide in Feverfew plants demonstrated that nanoparticles as elicitors are more effective; this effect was observed in $25 \mathrm{mM}$ and $24 \mathrm{~h}$ with $378.61 \mu \mathrm{g} / \mathrm{mg}$ and $136.02 \mu \mathrm{g} / \mathrm{mg}$, respectively [72]. Another study investigated the effects of foliar application of ZnO NPs in Camelina under salinity stress [77]. The synergy between $\mathrm{ZnO}$ NPs and salinity stress suggest that enhanced carotenoid content with $\mathrm{NaCl}(100 \mathrm{mM})$ and $\mathrm{ZnO}$ NPs $(40 \mathrm{mg} / \mathrm{L})$ and increment macroelements $(\mathrm{Ca}$ and $\mathrm{P})$ but principally could overcome the negative effects of salinity stress in Camelina at a concentration of $\mathrm{ZnO}$ NPs $(20 \mathrm{mg} / \mathrm{L})$ [77]. These studies demonstrated that NPs application as an elicitor can be helpful not only to improve the bioactive compound production but also could help plants exposed to negative stress conditions.

The topic of NPs elicitation in vitro cultures is gaining interest, yet there are few studies about their effects. The effectiveness of NPs as novel elicitors was also reported in in vitro systems with different results from the interaction with the primary and secondary metabolite of plants. In cell cultures, the principal interest is the production of commercially important bioactive compounds enhancing their production using tissue culture technology [83]. Principally, the production of secondary metabolism by cell/tissue culture is in medicinal plants [28]. The major aim of inducing bioactive compounds in medicinal plants using NPs is to increase therapeutic activity, which is attributed to its flavonoids, volatile oil, carotenoids, terpenoids, coumarins and alkaloids [84]. Singh et al. [65] investigated copper oxide NPs $(\mathrm{CuO})$ elicitation in the culture system; the authors reported an increase of total phenols (27.215 \pm 0.73 and $26.455 \pm 0.365 \mathrm{mg}$ gallic acid equivalents/g extract) in shoots and roots, flavonoid content $(23.076 \pm 0.5 .128 \mathrm{mg}$ quercetin equivalents $/ \mathrm{g}$ extract) in roots and antioxidant activity (55.797 \pm 1.924 and $56.811 \pm 3.012 \mathrm{mg}$ ascorbic acid equivalents/g extract) in shoots and roots in Withania somnifera L. Furthermore, Ag NPs elicitation has been used to improve indigo and tryptanthrin production $(1003 \mu \mathrm{g} / \mathrm{g}$ and $4.59 \pm 0.006 \mu \mathrm{g} / \mathrm{g}$ respectively) in Isatis treated with a concentration of $2(\mathrm{mg} / \mathrm{L})$ in plantlets harvested for five days, they exhibited an effect of 1.55 and 1.71 fold of control respectively [71]. Mosavat et al. [78] found that different Thymus species and Z. multiflora elicited with ZnO NPs (150 mg/L) in the culture system enhanced thymol and carvacrol content, such as T. kotshyanus and T. daenesis. Titanium dioxide nanoparticles $\left(\mathrm{TiO}_{2} \mathrm{NPs}\right)$ are one of the widest studies for improving bioactive compounds. A comparative study of NPs effects is the enhance of $\alpha$-tocopherol in vitro production of Argan using $\mathrm{TiO}_{2} \mathrm{NPs}$ and Silicon Dioxide $\left(\mathrm{SiO}_{2}\right)$ NPs as elicitors are reported in both NPs a concentration of $5 \mathrm{ppm}$ with $\mathrm{SiO}_{2} \mathrm{NPs}$ as mayor effect (4.59 and 4.7 fold of the control respectively) [73]. Ahmad et al. [69] studied $\mathrm{ZnO}$ and $\mathrm{CuO}$ NPs elicitation in candy leaf; they reported an increase of rebaudioside A $(4.42 \%)$, stevioside content (1.28\%), total phenolic content (5.86 $\mu \mathrm{g}$ gallic acid equivalent/mg), total flavonoid content $(6.25 \mu \mathrm{g} \mathrm{QE} / \mathrm{mg})$, total antioxidant activity $(9.09 \mu \mathrm{g} \mathrm{AAE} / \mathrm{mg})$, total reducing power $(11.04 \mu \mathrm{g} \mathrm{AAE} / \mathrm{mg})$ and \% DPPH inhibition (75.6\%) treatment with $2 \mathrm{mg} / \mathrm{L}$ of $\mathrm{ZnO}$. Under the elicitation of CuO NPs, the authors reported an increment of total phenolic content (4.55 $\mu$ g gallic acid equivalent $/ \mathrm{mg}$ ), total flavonoid content $(5.67 \mu \mathrm{g} \mathrm{QE} / \mathrm{mg})$, total antioxidant activity $(10.05 \mu \mathrm{g} \mathrm{AAE} / \mathrm{mg})$, 
total reducing power (12.04 $\mu \mathrm{g}$ AAE/mg) and \% DPPH inhibition (75.6\%) treatment with $20 \mathrm{mg} / \mathrm{L}$ [69].

The same synergistic effect between different types of NPs is also observed in vitro. The area of NPs elicitation in vitro cultures is gaining interest using only NPs or a mix of NPs, yet there are few studies about their effects. Fazal et al. [66] reported the enhancement of total phenol content (7.62 gallic acid equivalents $\mathrm{mg} / \mathrm{g}$ extract) and total flavonoids content ( 0.61 rutin equivalents $\mathrm{mg} / \mathrm{g}$ extract) with the combination of golden and silver $(\mathrm{AgAu}) \mathrm{NPs}(1: 3,30 \mu \mathrm{g} / \mathrm{L})$ and $2.0 \mathrm{mg}$ naphthalene acetic acid (NAA). Also, the authors reported an increment of DPPH-radical scavenging activity (87.8\%) compared to the control (83.64\%) [66]. Ali et al. [79] studied C. tuberculata elicited with Ag NPs in vitro, with results that indicate a decrease in biomass but an increase of fresh weight, total phenols content, total flavonoid content and PAL treatments with $90 \mu \mathrm{g} / \mathrm{L}$ concentration of Ag NPs.

In addition to biological activities such as antioxidants and anticancer, antimicrobial and antifungal activities can also be observed, the latter with a promising effect in agriculture. Ag NPs have been acknowledged as a novel and effective elicitor in plant biotechnology for the production of bioactive compounds [85]. Chung et al. [68] described the effect of Ag NPs $(0.5,1.0$ and $2.0 \mathrm{mg} / \mathrm{L})$ in hair root cultures of Cucumis anguria L.; they reported an enhancement of the biomass accumulation and enhancement of the total phenolic compounds ( 33.25 and $31.11 \mathrm{mg} / \mathrm{g}$ gallic acid equivalent, respectively) such as hydroxybenzoic acid, protocatechuic, syringic, $\beta$-resorcylic, vanillic acid, caffeic acid, chlorogenic, $\rho$-coumaric, ferulic, o-coumaric and $t$-cinnamic. Further, Ag NPs elicitation increased the antioxidant activity $(70.45 \%$ and $67.25 \%)$, antibacterial and antifungal activity and higher cancer cell inhibition at $200 \mu \mathrm{g} / \mathrm{mL}$ of extract in MCF-7 cell $(60.25 \%$ and $51.98 \%)$ and HT-39 cell (47.51\% and $43.19 \%)$ [68]. Since the amount of bioactive in plants is increased by the effect of NPs, it is expected that biological activities will also increase.

Nowadays, new areas of research for elicitation improved have used comparative research about different NPs, features and other biotic/abiotic elicitors. Researchers suggested both negative and positive effects on plant depends on the concentration, size, dose and plant species [86,87]. Particular attention has also been paid to the size of NPs, researchers reported the effect of $\mathrm{TiO}_{2} \mathrm{NPs}(<50 \mathrm{~nm}$ and $68 \mathrm{~nm})$ size in okra plants as elicitor increased seed germination in both sizes, also a decreased was observed in $\mathrm{Mg}$ and Fe in fruits [74]. Besides, Ogunkunle et al. [74] studied the effect of $\mathrm{TiO}_{2} \mathrm{NPs}$ at $50 \mathrm{~nm}$ size and $800 \mathrm{mg} / \mathrm{kg}$, which improved fresh weight in the fruits but which decreased at $68 \mathrm{~nm}$ and 200 and $800 \mathrm{mg} / \mathrm{kg}$ concentrations. In another study, various sizes $(10 \mathrm{~nm}, 40 \mathrm{~nm}$ and $100 \mathrm{~nm}$ ) of Ag NPs and concentrations (0.5-5.0 ppm) were tested in A. thaliana with increased camalexin, hydroxycamalexin O-hexoside, hydroxycamalexin alonylhexoside and others [75]. Kruska et al. [75] observed that Ag NPs change metabolites in A. thaliana based on differences between variants, time point effects and the interaction of variants and the time. Also, the effects of NPs in bioactive compounds production have to be carefully considered since can produce grown alteration or even toxicity effects.

These investigations illustrate the synergy effects in the biosynthesis of secondary metabolic induced by nanoparticles will depend on the nanomaterial used as an elicitor, plant species and the doses. Comparative research has explored new perspectives for novels elicitor using not only NPs alone but also in conjunction with other types of stress.

\section{Negative Impacts of Nanoparticles in Plants and Possible Risk in Human Health}

From the literature review presented, the positive and negative effects of NPs as potential elicitors in plants have been shown (Table 1). Despite the advantages that NPs present for improving bioactive compounds, a notorious negative effect caused by NPs in plants is toxicity $[88,89]$. NPs phytotoxicity cases are highly complex and depend on the physical and chemical properties, and also on the interaction between the plant and the environment [41]. Thus, NPs' toxic effects can depend on bulk material, size of the particles and doses, including precursors used for their preparation [90]. 
Several authors have suggested that the main mechanism underlying the toxicity in NPs is the production of ROS which is elevated in plants after exposure to NPs, resulting in oxidative stress in plant cells [36,41,91]. Under normal environmental conditions, ROS can enhance metabolic pathways [28], however, excessive amounts of ROS can subsequently lead to lipid peroxidation, damage in the cell membrane (proteins and DNA), resulting of potential cell death and physiological inhibition in plants. [39,92,93].

The majority of phytotoxicity is caused by the production of ROS, which affects the plant by altering their morphology, physiology, and biochemical and genetic constitutions [41]. Morphology changes in the grown potential, biomass and seed germination are commonly associated with toxicity effects to exposure to NPs [94,95]. Negative effects such as phytotoxicity have been observed in 200 and $300 \mathrm{mg} / \mathrm{L} \mathrm{ZnO} \mathrm{NPs} \mathrm{treatments,}$ reducing the $A$. thaliana grown by $20 \%$ and $80 \%$, respectively, as well as the inhibition of the expression of chlorophyll synthesis genes and photosystem structure genes [96]. However, NPs can be more toxic than their bulk form due to their surface being significantly larger and due to free radical production through the release of metal ions [97,98]. For example, Hong et al. [99] reported that all $\mathrm{Cu}$ NPs and $\mathrm{Cu}$ compounds reduced the root length by $49 \%$, increased ascorbate peroxidase activity in roots in L. sativa and M. sativa reduced the size of the plant and altered the nutrient content. Moreover, concerns about toxicity effects in aquatic plants have also been investigated, demonstrating that $\mathrm{CuO}$ NPs induce growth inhibition, a significant decrease of carotenoids level and an increase of ROS in $C$. reinhardtii [100].

Plants are highly consumed by humans and animals and the NPs can be absorbed into their organs and can bioaccumulate in the tissues that are then used for consumption [41]. Due to the potential use of NPs as a novel elicitor for bioactive compounds and their use in field-scale application in human products (ex. food), there is a focus on safety issues including phytotoxicity and toxic effects in human health. Before using NPs in the agrofood sector it is necessary to research biosafety in the life cycle, uptake and translocation by plants and the entrance into the food chain (direct and indirect way) [36]. Further, according to Kirchner et al. [101], NPs can have toxic effects in any organism through the releases of toxic metals used as a precursor for synthesis, the interaction between NPs and the surface of cell membranes and due to their size or shape.

In animals and humans, several risks are related to the safety of NPs which are associated with toxicity and can potentially cause inflammation, oxide stress, DNA damage, proteins damage, carcinogenesis, fibrosis and cell death [102-104]. Even though the benefits of NPs are known, potential risk issues need to be considered, since they could enter the human body by different pathways such as oral exposure due to food, water, air, nanofood or drugs that contain nanomaterials [105]. It is necessary to better understand the biosafety issues in order to reduce a knowledge gap about NPs' toxic effects upon entering a different organism. This review only presents possible causes and issues that could arise for NPs in diverse applications.

\section{Conclusions and Perspectives}

This review suggests that NPs can be a promising tool to improve quality, quantity and commercial features such as storage life (ex. Jalapeño pepper) through bioactive compounds' elicitation. Besides, the impact of NPs as a novel elicitor is not only limited to a secondary metabolism stimulant but can also improve the primary metabolism in plants. This impact depends on the route of application use, type of material, uptake and translocation of NPs that interacted with the plant cells and their secondary metabolism pathways.

Enhanced synthesis of secondary metabolites production includes flavonoids, carotenoids, alkaloids, volatile oils, taxol and so forth; elicitation is recognized as the most practical strategy for increasing the production of desirable bioactive compounds. The improved production of bioactive compounds through nanoparticles as elicitors has unlocked a new area of research that could have a significant impact on the food, pharmaceutical and medical industries. 
Nowadays, the application of nanoparticles as elicitors is currently focusing on improving the biosynthesis of secondary metabolites. However, recent studies have explored an interesting and promising perspective of research that includes the application of current options for elicitation and nanoparticles [77]. Also, this new line of research investigates the synergistic effects of nanomaterials with other abiotic/biotic elicitors. An example is the investigation of Khajavi et al. [72], who investigated the effect of titanium dioxide $\mathrm{NPs}\left(\mathrm{TiO}_{2}\right)$, silica oxide NPs $\left(\mathrm{SiO}_{2}\right)$ and salinity stress in Feverfew (Tanacetum parthenium L.) as elicitors. Additionally, scientists and industry continue their research to determine the critical doses of nanoparticles without phytotoxicity and the mechanisms involved in bioactive compounds' production by plants resulting from nanoparticle application.

Moreover, the literature is still limited to the study of the effect of nanoparticles on the progression and development of different plant tissues and cells, as well as the effect induced in the pathways of secondary metabolism. The current research showed that nanomaterials can be used as elicitors to improve the biosynthesis of bioactive compounds and principally, the application of nanoparticles in medicinal plants as a strategy to enhance the biological activity without phytotoxicity. However, the application of nanomaterials as an elicitor needs more investigation on the potential effects on ecosystems and on human risk. Furthermore, for large-scale field-like conditions, more studies on the interaction between plants and nanomaterials in terms of doses, time, type of exposure and others may be necessary.

Author Contributions: S.d.J.R.-M. was responsible for reviewing the literature and writing the paper. I.T.-P. was responsible for managing the team and the conception of the research topic. M.V.-H. was in charge of reviewing the manuscript. All authors have read and agreed to the published version of the manuscript.

Funding: Please add: I. Torres Pacheco acknowledges CONACYT Ciencia Básica for grant A1-S-33677.

Institutional Review Board Statement: Not applicable.

Informed Consent Statement: Not applicable.

Acknowledgments: S.d.J.R.-M. acknowledges Consejo Nacional de Ciencia y Tecnología (CONACYT) for providing scholarships for postgrad degree (grant 710285).

Conflicts of Interest: The authors declare that the research was conducted in the absence of any commercial or financial relationships that could be construed as a potential conflict of interest.

\section{References}

1. International Food Information Service (Ed.) Dictionary of Food Science and Technology, 2nd ed.; John \& Wiley \& Sons: Hoboken, NJ, USA, 2009; pp. 47-48.

2. Reiss, R.; Johnston, J.; Tucker, K.; DeSesso, J.M.; Keen, C.L. Estimation of cancer risks and benefits associated with a potential increased consumption of fruits and vegetables. Food Chem. Toxicol. 2012, 50, 4421-4427. [CrossRef]

3. Slavin, J.L.; Lloyd, B. Health benefits of fruits and vegetables. Adv. Nutr. 2012, 3, 506-516. [CrossRef]

4. Rodriguez-Casado, A. The health potential of fruits and vegetables phytochemicals: Notable examples. Crit. Rev. Food Sci. 2014, 56, 1097-1107. [CrossRef]

5. Liu, R.H. Dietary bioactive compounds and their health implications. J. Food Sci. 2013, 78, A18-A25. [CrossRef]

6. Vincente, A.R.; Manganaris, G.A.; Ortiz, C.M.; Sozzi, G.O.; Crisosto, C.H. Chapter 5-Nutritional quality of fruits and vegetables. In Postharvest Handling, 3rd ed.; Florkowski, W.J., Shewfelt, R.L., Brueckner, B., Prussia, S.E., Eds.; Academic Press: Cambridge, MA, USA, 2014; pp. 97-103. [CrossRef]

7. Guaadaoui, A.; Benaicha, S.; Elmajdoub, N.; Bellaoui, M.; Hamal, A. What is a bioactive compound? A combined definition for a preliminary consensus. Int. J. Nutr. Food Sci. 2014, 3, 174-179. [CrossRef]

8. Naik, P.M.; Al-Khayri, J.M. Abiotic and biotic elicitors-role in secondary metabolites production through in vitro culture of medicinal plants. In Abiotic and Biotic Stress in Plants-Recent Advances and Future Perspectives; Shanker, A.K., Shanker, C., Eds.; IntechOpen Limited: London, UK, 2016; pp. 247-277. [CrossRef]

9. Shitan, N. Secondary metabolites in plants: Transport and self-tolerance mechanisms. Biosci. Biotechnol. Biochem. 2016, 80, 1283-1293. [CrossRef]

10. Jafari, S.M.; McClements, D.J. Chapter One-Nanotechnology approaches for increasing nutrient bioavailability. In Advances in Food and Nutrition Research, 1st ed.; Toldrá, F., Ed.; Academic Press: London, UK, 2017; Volume 81, pp. 1-30. [CrossRef]

11. Dixon, R.A. Natural products and plant disease resistance. Nature 2001, 411, 843-847. [CrossRef] [PubMed] 
12. Namdeo, A.G. Plant cell elicitation for production of secondary metabolites: A review. Pharmacogn. Rev. 2007, 1, 69-79.

13. Parola-Contreras, I.; Tovar-Perez, E.G.; Rojas-Molina, A.; Luna-Vazquez, F.J.; Torres-Pacheco, I.; Ocampo-Velazquez, R.V.; Guevara-González, R.G. Changes in affinin contents in Heliopsis longipes (chilcuague) after a controlled elicitation strategy under greenhouse conditions. Ind. Crops Prod. 2020, 148, 112314. [CrossRef]

14. Vargas-Hernandez, M.; Macias-Bobadilla, I.; Guevara-Gonzalez, R.G.; Rico-Garcia, E.; Ocampo-Velazquez, R.V.; Avila-Juarez, L.; Torres-Pacheco, I. Nanoparticles as Potential Antivirals in Agriculture. Agriculture 2020, 10, 444. [CrossRef]

15. Ashraf, M.A.; Iqbal, M.; Rasheed, R.; Hussain, I.; Riaz, M.; Arif, M.S. Chapter 8-Environmental Stress and Secondary Metabolites in Plants: An Overview. In Plant Metabolites and Regulation under Environmental Stress; Ahmad, P., Ahanger, M.P., Singh, V.P., Tripathi, D.K., Alam, P., Alyemeni, M.N., Eds.; Academic Press: Cambridge, MA, USA, 2018; pp. 153-167. [CrossRef]

16. Sarin, R. Useful metabolites from plant tissue cultures. Biotechnology 2005, 4, 79-93. [CrossRef]

17. Tian, H.; Ghorbanpour, M.; Kariman, K. Manganese oxide nanoparticle-induced changes in growth, redox reactions and elicitation of antioxidant metabolites in deadly nightshade (Atropa belladonna L.). Ind. Crops Prod. 2018, 126, 403-414. [CrossRef]

18. Hasan, S. A review on nanoparticles: Their synthesis and types. Res. J. Recent Sci. 2015, 2277, 2502.

19. Joshi, H.; Choudhary, P.; Mundra, S. Future prospects of nanotechnology in agriculture. Int. J. Chem. Stud. 2019, 7, 957-963.

20. Lira Saldivar, R.H.; Méndez Argüello, B.; Santos Villarreal, G.D.L.; Vera Reyes, I. Potencial de la nanotecnología en la agricultura. Acta Univ. 2018, 28, 9-24. [CrossRef]

21. Dubchak, S.; Ogar, A.; Mietelski, J.W.; Turnau, K. Influence of silver and titanium nanoparticles on arbuscular mycorrhiza colonization and accumulation of radiocaesium in Helianthus annuus. Span. J. Agric. Res. 2010, 1, 103-108. [CrossRef]

22. Duhan, J.S.; Kumar, R.; Kumar, N.; Kaur, P.; Nehra, K.; y Duhan, S. Nanotechnology: The new perspective in precision agriculture. Biotechnol. Rep. 2017, 15, 11-23. [CrossRef]

23. Prasad, R.; Bhattacharyya, A.; Nguyen, Q.D. Nanotechnology in sustainable agriculture: Recent developments, challenges, and perspectives. Front. Microbiol. 2017, 8, 1014. [CrossRef]

24. Fraceto, L.F.; Grillo, R.; de Medeiros, G.A.; Scognamiglio, V.; Rea, G.; Bartolucci, C. Nanotechnology in agriculture: Which innovation potential does it have? Front. Environ. Sci. 2016, 4, 20. [CrossRef]

25. Marslin, G.; Sheeba, C.J.; Franklin, G. Nanoparticles alter secondary metabolism in plants via ROS burst. Front. Plant Sci. 2017, 8, 832. [CrossRef]

26. Singh, S.; Vishwakarma, K.; Singh, S.; Sharma, S.; Dubey, N.K.; Singh, V.K.; Liu, S.; Tripathi, D.K.; Chauhan, D.K. Understanding the plant and nanoparticle interface at transcriptomic and proteomic level: A concentric overview. Plant Gene 2017, 11, 265-272. [CrossRef]

27. Zuverza-Mena, N.; Martínez-Fernández, D.; Du, W.; Hernandez-Viezcas, J.A.; Bonilla-Bird, N.; López-Moreno, M.L.; GardeaTorresdey, J.L. Exposure of engineered nanomaterials to plants: Insights into the physiological and biochemical responses-A review. Plant Physiol. Biochem. 2017, 110, 236-264. [CrossRef]

28. Hatami, M.; Naghdi Badi, H.; Ghorbanpour, M. Nano-elicitation of secondary pharmaceutical metabolites in plant cells: A review. J. Med. Plants 2019, 18, 6-36. [CrossRef]

29. Anjum, S.; Anjum, I.; Hano, C.; Kousar, S. Advances in nanomaterials as novel elicitors of pharmacologically active plant specialized metabolites: Current status and future outlooks. RSC Adv. 2019, 9, 40404-40423. [CrossRef]

30. Zobayed, S.M.A.; Afreen, F.; Kozai, T. Temperature stress can alter the photosynthetic efficiency and secondary metabolite concentrations in St. John's wort. Plant Physiol. Biochem. 2005, 43, 977-984. [CrossRef] [PubMed]

31. Agnihotri, S.; Mukherji, S.; Mukherji, S. Size-controlled silver nanoparticles synthesized over the range 5-100 nm using the same protocol and their antibacterial efficacy. RSC Adv. 2014, 4, 3974-3983. [CrossRef]

32. Dakal, T.C.; Kumar, A.; Majumdar, R.S.; Yadav, V. Mechanistic basis of antimicrobial actions of silver nanoparticles. Front. Microb. 2016, 7, 1831. [CrossRef] [PubMed]

33. Salatin, S.; Maleki Dizaj, S.; Yari Khosroushahi, A. Effect of the surface modification, size, and shape on cellular uptake of nanoparticles. Cell Biol. Int. 2015, 39, 881-890. [CrossRef]

34. Hu, P.; An, J.; Faulkner, M.M.; Wu, H.; Li, Z.; Tian, X.; Giraldo, J.P. Nanoparticle Charge and Size Control Foliar Delivery Efficiency to Plant Cells and Organelles. ACS Nano 2020, 14, 7970-7986. [CrossRef]

35. Lee, S.H.; Jun, B.H. Silver nanoparticles: Synthesis and application for nanomedicine. Int. J. Mol. Sci. 2019, 20, 865. [CrossRef]

36. Rico, C.M.; Majumdar, S.; Duarte-Gardea, M.; Peralta-Videa, J.R.; Gardea-Torresdey, J.L. Interaction of nanoparticles with edible plants and their possible implications in the food chain. J. Agric. Food Chem. 2011, 59, 3485-3498. [CrossRef]

37. Lew, T.T.S.; Wong, M.H.; Kwak, S.Y.; Sinclair, R.; Koman, V.B.; Strano, M.S. Rational design principles for the transport and subcellular distribution of nanomaterials into plant protoplasts. Small 2018, 14, 1802086. [CrossRef]

38. Wang, Z.; Xie, X.; Zhao, J.; Liu, X.; Feng, W.; White, J.C.; Xing, B. Xylem-and phloem-based transport of CuO nanoparticles in maize (Zea mays L.). Environ. Sci. Technol. 2012, 46, 4434-4441. [CrossRef]

39. Rico, C.M.; Peralta-Videa, J.R.; Gardea-Torresdey, J.L. Nanotechnology and Plant Sciences; Siddiqui, M., Al-Whaibi, M., Mohammad, F., Eds.; Springer: Cham, Switzerland, 2015; pp. 1-17. [CrossRef]

40. Gupta, S.D.; Agarwal, A.; Pradhan, S. Phytostimulatory effect of silver nanoparticles (AgNPs) on rice seedling growth: An insight from antioxidative enzyme activities and gene expression patterns. Ecotoxicol. Environ. Saf. 2018, 161, 624-633. [CrossRef] 
41. Tripathi, D.K.; Singh, S.; Singh, S.; Pandey, R.; Singh, V.P.; Sharma, N.C.; Prasad, S.M.; Dubey, N.K.; Chauhan, D.K. An overview on manufactured nanoparticles in plants: Uptake, translocation, accumulation and phytotoxicity. Plant Physiol. Biochem. 2017, 110, 2-12. [CrossRef] [PubMed]

42. Avellan, A.; Yun, J.; Zhang, Y.; Spielman-Sun, E.; Unrine, J.M.; Thieme, J.; Lowry, G.V. Nanoparticle size and coating chemistry control foliar uptake pathways, translocation, and leaf-to-rhizosphere transport in wheat. ACS Nano 2019, 13, 5291-5305. [CrossRef] [PubMed]

43. Ali, A.; Hira Zafar, M.Z.; ul Haq, I.; Phull, A.R.; Ali, J.S.; Hussain, A. Synthesis, characterization, applications, and challenges of iron oxide nanoparticles. Nanotechnol. Sci. Appl. 2016, 9, 49. [CrossRef]

44. Truong, N.P.; Whittaker, M.R.; Mak, C.W.; Davis, T.P. The importance of nanoparticle shape in cancer drug delivery. Expert Opin. Drug Deliv. 2015, 12, 129-142. [CrossRef]

45. Raliya, R.; Franke, C.; Chavalmane, S.; Nair, R.; Reed, N.; Biswas, P. Quantitative understanding of nanoparticle uptake in watermelon plants. Front. Plant Sci. 2016, 7, 1288. [CrossRef]

46. Dasgupta, S.; Auth, T.; Gompper, G. Shape and orientation matter for the cellular uptake of nonspherical particles. Nano Lett. 2014, 14, 687-693. [CrossRef] [PubMed]

47. Agarwal, R.; Jurney, P.; Raythatha, M.; Singh, V.; Sreenivasan, S.V.; Shi, L.; Roy, K. Effect of shape, size, and aspect ratio on nanoparticle penetration and distribution inside solid tissues using 3D spheroid models. Adv. Healthc. Mater. 2015, 4, 2269-2280. [CrossRef]

48. Chhabra, H.; Kumar, M. Modeling for size and shape dependence of critical temperature for different type of nanomaterials. J. Phys. Chem. Solids 2019, 135, 109075. [CrossRef]

49. Bhatt, S.; Kumar, M. Effect of size and shape on melting and superheating of free standing and embedded nanoparticles. J. Phys. Chem. Solids 2017, 106, 112-117. [CrossRef]

50. Buzea, C.; Pacheco, I. Nanomaterial and nanoparticle: Origin and activity. In Nanoscience and Plant-Soil Systems. Soil Biology; Ghorbanpour, M., Manika, K., Varma, A., Eds.; Springer: Cham, Switzerland, 2017; Volume 48, pp. 71-112. [CrossRef]

51. Bhushan, B. Introduction to nanotechnology. In Springer Handbook of Nanotechnology; Springer: Berlin/Heidelberg, Germany, 2017; pp. 1-19. [CrossRef]

52. Zhang, W.; Ebbs, S.; Musante, C.; White, J.; Gao, C.; Ma, X. Uptake and accumulation of bulk and nano-sized cerium oxide particles and ionic cerium by radish (Raphanus satious L.). J. Agric. Food Chem. 2015, 63, 382-390. [CrossRef]

53. Ebbs, S.D.; Bradfield, S.J.; Kumar, P.; White, J.C.; Musante, C.; Ma, X. Accumulation of zinc, copper, or cerium in carrot (Daucus carota) exposed to metal oxide nanoparticles and metal ions. Environ. Sci. Nano 2016, 3, 114-126. [CrossRef]

54. Bradfield, S.J.; Kumar, P.; White, J.C.; Ebbs, S.D. Zinc, copper, or cerium accumulation from metal oxide nanoparticles or ions in sweet potato: Yield effects and projected dietary intake from consumption. Plant Physiol. Biochem. 2017, 110, 128-137. [CrossRef] [PubMed]

55. Yarizade, K.; Hosseini, R. Expression analysis of ADS, DBR2, ALDH1 and SQS genes in Artemisia vulgaris hairy root culture under nano cobalt and nano zinc elicitation. Ext. J. App. Sci. 2015, 3, 69-76.

56. Hasanuzzaman, M.; Bhuyan, M.H.M.; Zulfiqar, F.; Raza, A.; Mohsin, S.M.; Mahmud, J.A.; Fotopoulos, V. Reactive oxygen species and antioxidant defense in plants under abiotic stress: Revisiting the crucial role of a universal defense regulator. Antioxidants 2020, 9, 681. [CrossRef]

57. Vannini, C.; Domingo, G.; Onelli, E.; Prinsi, B.; Marsoni, M.; Espen, L.; Bracale, M. Morphological and proteomic responses of Eruca sativa exposed to silver nanoparticles or silver nitrate. PLoS ONE 2013, 8, 68-75. [CrossRef] [PubMed]

58. Tassi, E.; Giorgetti, L.; Morelli, E.; Peralta-Videa, J.R.; Gardea-Torresdey, J.L.; Barbafieri, M. Physiological and biochemical responses of sunflower (Helianthus annuus L.) exposed to nano- $\mathrm{CeO}_{2}$ and excess boron: Modulation of boron phytotoxicity. Plant Physiol. Biochem. 2017, 110, 50-58. [CrossRef]

59. Juarez-Maldonado, A.; Ortega-Ortíz, H.; Pérez-Labrada, F.; Cadenas-Pliego, G.; Benavides-Mendoza, A. Cu Nanoparticles absorbed on chitosan hydrogels positively alter morphological, production, and quality characteristics of tomato. J. Appl. Bot. Food Qual. 2016, 89. [CrossRef]

60. Pinedo-Guerrero, Z.H.; Hernández-Fuentes, A.D.; Ortega-Ortiz, H.; Benavides-Mendoza, A.; Cadenas-Pliego, G. Cu nanoparticles in hydrogels of chitosan-PVA affects the characteristics of post-harvest and bioactive compounds of jalapeño pepper. Molecules 2017, 22, 926. [CrossRef]

61. Večeřová, K.; Večeřa, Z.; Dočekal, B.; Oravec, M.; Pompeiano, A.; Tř́íska, J.; Urban, O. Changes of primary and secondary metabolites in barley plants exposed to CdO nanoparticles. Environ. Pollut. 2016, 218, 207-218. [CrossRef]

62. Zhao, L.; Hu, J.; Huang, Y.; Wang, H.; Adeleye, A.; Ortiz, C.; Keller, A.A. 1H NMR and GC-MS based metabolomics reveal nano-Cu altered cucumber (Cucumis sativus) fruit nutritional supply. Plant Physiol. Biochem. 2017, 110, 138-146. [CrossRef]

63. Barrios, A.C.; Medina-Velo, I.A.; Zuverza-Mena, N.; Dominguez, O.E.; Peralta-Videa, J.R.; Gardea-Torresdey, J.L. Nutritional quality assessment of tomato fruits after exposure to uncoated and citric acid coated cerium oxide nanoparticles, bulk cerium oxide, cerium acetate and citric acid. Plant Physiol. Biochem. 2017, 110, 100-107. [CrossRef]

64. Ghanati, F.; Bakhtiarian, S. Effect of methyl jasmonate and silver nanoparticles on production of secondary metabolites by Calendula officinalis L (Asteraceae). Trop. J. Pharm. Res. 2014, 13, 1783-1789. [CrossRef]

65. Singh, O.S.; Pant, N.C.; Laishram, L.; Tewari, M.; Dhoundiyal, R.; Joshi, K.; Pandey, C. Effect of CuO nanoparticles on polyphenols content and antioxidant activity in Ashwagandha (Withania somnifera L. Dunal). J. Pharmacogn. Phytochem. 2018, 7, $3433-3439$. 
66. Fazal, H.; Abbasi, B.H.; Ahmad, N.; Ali, M.; Shujait Ali, S.; Khan, A.; Wei, D.Q. Sustainable production of biomass and industrially important secondary metabolites in cell cultures of selfheal (Prunella vulgaris L.) elicited by silver and gold nanoparticles. Artif. Cells Nanomed. Biotechnol. 2019, 47, 2553-2561. [CrossRef]

67. Jamshidi, M.; Ghanati, F. Taxanes content and cytotoxicity of hazel cells extract after elicitation with silver nanoparticles. Plant Physiol. Biochem. 2017, 110, 178-184. [CrossRef] [PubMed]

68. Chung, I.M.; Rajakumar, G.; Thiruvengadam, M. Effect of silver nanoparticles on phenolic compounds production and biological activities in hairy root cultures of Cucumis anguria. Acta Biol. Hung. 2018, 69, 97-109. [CrossRef] [PubMed]

69. Ahmad, M.A.; Javed, R.; Adeel, M.; Rizwan, M.; Ao, Q.; Yang, Y. Engineered ZnO and CuO Nanoparticles Ameliorate Morphological and Biochemical Response in Tissue Culture Regenerants of Candyleaf (Stevia rebaudiana). Molecules 2020, 25, 1356. [CrossRef] [PubMed]

70. Sharifi-Rad, R.; Bahabadi, S.E.; Samzadeh-Kermani, A.; Gholami, M. The Effect of Non-biological Elicitors on Physiological and Biochemical Properties of Medicinal Plant Momordica charantia L. Iran. J. Sci. Technol. Trans. A Sci. 2020, 44, 1315-1326. [CrossRef]

71. Karakas, O. Effect of Silver Nanoparticles on Production of Indole Alkaloids in Isatis constricta. Iran. J. Sci. Technol. Trans. A Sci. 2020, 44, 621-627. [CrossRef]

72. Khajavi, M.; Rahaie, M.; Ebrahimi, A. The effect of $\mathrm{TiO}_{2}$ and $\mathrm{SiO}_{2}$ nanoparticles and salinity stress on expression of genes involved in parthenolide biosynthesis in Feverfew (Tanacetum parthenium L.). Caryologia Int. J. Cytol. Cytosyst. Cytogenet. 2019, 72, 3-14. [CrossRef]

73. Hegazi, G.A.; Ibrahim, W.M.; Hendawy, M.H.; Salem, H.M.; Ghareb, H.E. Improving $\alpha$-Tocopherol Accumulation in Argania Spinosa Suspension Cultures by Precursor and Nanoparticles Feeding. Plant Arch. 2020, 20, 2431-2437. [CrossRef]

74. Kruszka, D.; Sawikowska, A.; Selvakesavan, R.K.; Krajewski, P.; Kachlicki, P.; Franklin, G. Silver nanoparticles affect phenolic and phytoalexin composition of Arabidopsis thaliana. Sci. Total Environ. 2020, 716, 135361. [CrossRef] [PubMed]

75. Ogunkunle, C.O.; Adegboye, E.F.; Okoro, H.K.; Vishwakarma, V.; Alagarsamy, K.; Fatoba, P.O. Effect of nanosized anatase TiO 2 on germination, stress defense enzymes, and fruit nutritional quality of Abelmoschus esculentus (L.) Moench (okra). Arab. J. Geosci. 2020, 13, 120. [CrossRef]

76. Li, D.; An, Q.; Wu, Y.; Li, J.Q.; Pan, C. Foliar application of selenium nanoparticles on celery stimulates several nutrient component levels by regulating the $\alpha$-linolenic acid pathway. ACS Sustain. Chem. Eng. 2020, 8, 10502-10510. [CrossRef]

77. Hezaveh, T.A.; Rahmani, F.; Alipour, H.; Pourakbar, L. Effects of Foliar Application of ZnO Nanoparticles on Secondary Metabolite and Micro-elements of Camelina (Camelina sativa L.) Under Salinity Stress. J. Stress Physiol. Biochem. 2020, 16, 54-69.

78. Mosavat, N.; Golkar, P.; Yousefifard, M.; Javed, R. Modulation of callus growth and secondary metabolites in different Thymus species and Zataria multiflora micropropagated under ZnO nanoparticles stress. Biotechnol. Appl. Biochem. 2019, 66, 316-322. [CrossRef]

79. Ali, A.; Mohammad, S.; Khan, M.A.; Raja, N.I.; Arif, M.; Kamil, A.; Mashwani, Z. Silver nanoparticles elicited in vitro callus cultures for accumulation of biomass and secondary metabolites in Caralluma tuberculata. Artif. Cells Nanomed. Biotechnol. 2019, 47, 715-724. [CrossRef] [PubMed]

80. Khan, M.A.; Wallace, W.T.; Sambi, J.; Rogers, D.T.; Littleton, J.M.; Rankin, S.E.; Knutson, B.L. Nanoharvesting of bioactive materials from living plant cultures using engineered silica nanoparticles. Mater. Sci. Eng. C Mater. Biol. Appl. 2020, 106, 110190. [CrossRef]

81. Tsao, R. Chemistry and biochemistry of dietary polyphenols. Nutrients 2010, 2, 1231-1246. [CrossRef] [PubMed]

82. Fu, P.P.; Xia, Q.; Hwang, H.M.; Ray, P.C.; Yu, H. Mechanisms of nanotoxicity: Generation of reactive oxygen species. J. Food Drug Anal. 2014, 22, 64-75. [CrossRef]

83. Zhang, B.; Zheng, L.P.; Yi Li, W.; Wen Wang, J. Stimulation of artemisinin production in Artemisia annua hairy roots by Ag-SiO 2 core-shell nanoparticles. Curr. Nanosci. 2013, 9, 363-370. [CrossRef]

84. Muley, B.P.; Khadabadi, S.S.; Banarase, N.B. Phytochemical constituents and pharmacological activities of Calendula officinalis Linn (Asteraceae): A review. Trop. J. Pharm. Res. 2009, 8. [CrossRef]

85. Rezaei, A.; Ghanati, F.; Behmanesh, M.; Mokhtari-Dizaji, M. Ultrasound-potentiated salicylic acid-induced physiological effects and production of taxol in hazelnut (Corylus avellana L.) cell culture. Ultrasound Med. Biol. 2011, 37, 1938-1947. [CrossRef]

86. Ma, X.; Geiser-Lee, J.; Deng, Y.; Kolmakov, A. Interactions between engineered nanoparticles (ENPs) and plants: Phytotoxicity, uptake and accumulation. Sci. Total Environ. 2010, 408, 3053-3061. [CrossRef]

87. Khodakovskaya, M.V.; Kim, B.S.; Kim, J.N.; Alimohammadi, M.; Dervishi, E.; Mustafa, T.; Cernigla, C.E. Carbon nanotubes as plant growth regulators: Effects on tomato growth, reproductive system, and soil microbial community. Small 2013, 9, 115-123. [CrossRef] [PubMed]

88. Siddiqui, M.H.; Al-Whaibi, M.H. Role of nano-SiO ${ }_{2}$ in germination of tomato (Lycopersicum esculentum seeds Mill). Saudi J. Biol. Sci. 2014, 21, 13-17. [CrossRef] [PubMed]

89. Siddiqui, M.H.; Al-Whaibi, M.H.; Mohammad, F. Nanotechnology and Plant Sciences: Nanoparticles and Their Impact on Plants; Springer International Publishing: Cham, Switzerland, 2015; Volume 978, 303p.

90. Srivastava, V.; Gusain, D.; Sharma, Y.C. Critical review on the toxicity of some widely used engineered nanoparticles. Ind. Eng. Chem. Res. 2015, 54, 6209-6233. [CrossRef] 
91. Nair, R.; Varghese, S.H.; Nair, B.G.; Maekawa, T.; Yoshida, Y.; Kumar, D.S. Nanoparticulate material delivery to plants. Plant Sci. 2010, 179, 154-163. [CrossRef]

92. Yan, A.; Chen, Z. Impacts of silver nanoparticles on plants: A focus on the phytotoxicity and underlying mechanism. Int. J. Mol. Sci. 2019, 20, 1003. [CrossRef]

93. Capaldi Arruda, S.C.; Diniz Silva, A.L.; Moretto Galazzi, R.; Antunes Azevedo, R.; Zezzi Arruda, M.A. Nanoparticles applied to plant science: A review. Talanta 2015, 131, 693-705. [CrossRef] [PubMed]

94. Dietz, K.-J.; Herth, S. Plant nanotoxicology. Trends Plant Sci. 2011, 16, 582-589. [CrossRef] [PubMed]

95. Aslani, F.; Bagheri, S.; Muhd Julkapli, N.; Juraimi, A.S.; Hashemi, F.S.G.; Baghdadi, A. Effects of engineered nanomaterials on plants growth: An overview. Sci. World J. 2014, 2014. [CrossRef]

96. Wang, X.; Yang, X.; Chen, S.; Li, Q.; Wang, W.; Hou, C.; Wang, S. Zinc oxide nanoparticles affect biomass accumulation and photosynthesis in Arabidopsis. Front. Plant Sci. 2016, 6, 1243. [CrossRef]

97. Sharifi, S.; Behzadi, S.; Laurent, S.; Forrest, M.L.; Stroeve, P.; Mahmoudi, M. Toxicity of nanomaterials. Chem. Soc. Rev. 2012, 41, 2323-2343. [CrossRef]

98. Mortezaee, K.; Najafi, M.; Samadian, H.; Barabadi, H.; Azarnezhad, A.; Ahmadi, A. Redox interactions and genotoxicity of metal-based nanoparticles: A comprehensive review. Chem. Biol. Interact. 2019, 312, 108814. [CrossRef] [PubMed]

99. Hong, J.; Rico, C.M.; Zhao, L.; Adeleye, A.S.; Keller, A.A.; Peralta-Videa, J.R.; Gardea-Torresdey, J.L. Toxic effects of copper-based nanoparticles or compounds to lettuce (Lactuca sativa) and alfalfa (Medicago sativa). Environ. Sci. Process. Impacts 2015, 17, 177-185. [CrossRef]

100. Melegari, S.P.; Perreault, F.; Costa, R.H.R.; Popovic, R.; Matias, W.G. Evaluation of toxicity and oxidative stress induced by copper oxide nanoparticles in the green alga Chlamydomonas reinhardtii. Aquat. Toxicol. 2013, 142, 431-440. [CrossRef] [PubMed]

101. Kirchner, C.; Liedl, T.; Kudera, S.; Pellegrino, T.; Muñoz Javier, A.; Gaub, H.E.; Stölzle, S.; Fertig, N.; Parak, W.J. Cytotoxicity of Colloidal CdSe and CdSe/ZnS Nanoparticles. Nano Lett. 2005, 5, 331. [CrossRef]

102. Li, N.; Xia, T.; Nel, A.E. The role of oxidative stress in ambient particulate matter-induced lung diseases and its implications in the toxicity of engineered nanoparticles. Free Radic. Biol. Med. 2008, 44, 1689-1699. [CrossRef]

103. Abdal Dayem, A.; Hossain, M.K.; Lee, S.B.; Kim, K.; Saha, S.K.; Yang, G.M.; Cho, S.G. The role of reactive oxygen species (ROS) in the biological activities of metallic nanoparticles. Int. J. Mol. Sci. 2017, 18, 120. [CrossRef] [PubMed]

104. Stone, V.; Johnston, H.; Clift, M.J. Air pollution, ultrafine and nanoparticle toxicology: Cellular and molecular interactions. IEEE Trans. Nanobiosci. 2007, 6, 331-340. [CrossRef]

105. Karimi, M.; Sadeghi, R.; Kokini, J. Human exposure to nanoparticles through trophic transfer and the biosafety concerns that nanoparticle-contaminated foods pose to consumers. Trends Food Sci. Technol. 2018, 75, 129-145. [CrossRef] 